\title{
Immunohistochemical Evaluation of the Inflammatory Response in Periodontal Disease
}

\author{
Ruthinéia Diógenes Alves Uchôa LINS ${ }^{1}$ \\ Cláudia Roberta Leite Vieira FIGUEIREDO² \\ Lélia Maria Guedes QUEIROZ ${ }^{3}$ \\ Ericka Janine Dantas da SILVEIRA ${ }^{4}$ \\ Gustavo Pina GODOY ${ }^{3}$ \\ Roseana de Almeida FREITAS ${ }^{3}$
${ }^{1}$ Department of Periodontics, University of the State of Paraíba, Campina Grande, PB, Brazil
${ }^{2}$ Department of Pathology, Federal University of Paraíba, João Pessoa, PB, Brazil
${ }^{3}$ Department of Oral Pathology, School of Dentistry, Health Sciences Center,
Federal University of Rio Grande do Norte, Natal, RN, Brazil
${ }^{4}$ Department of Dentistry, State University of Rio Grande do Norte, Caicó, RN, Brazil

\begin{abstract}
In order to contribute to the knowledge of the pathogenesis of periodontal disease, an immunohistochemical analysis of the density of inflammatory mononucleated cells and the number of dendritic cells was performed using anti-CD4, anti-CD20, anti-CD25, anti-CD68 and anti-protein S-100 antibodies in 17 cases of chronic gingivitis (CG) and 25 of chronic periodontitis (CP). The CD4+ and CD68+ cells exhibited a diffuse distribution in the connective tissue. CD20+ cell distribution was predominantly in groups and the CD25+cells exhibited a diffuse or focal distribution. The S-100+ cells were identified in the epithelium and the lamina propria, exhibiting distinct morphology and number. The statistical analysis showed no significant differences ( $p>0.05$ ) between $\mathrm{CG}$ and $\mathrm{CP}$ regarding the density of the CD4+ and CD20+ cells and the number of S-100+ cells. However, significant differences $(\mathrm{p}<0.05)$ were found between the groups in the density of CD25+ and CD68+ cells . The density of macrophages was greater in CG and the level of cellular activation of the lymphocyte infiltrate was greater in CP. No differences were detected between the aforementioned conditions regarding the density of the T and B lymphocytes and to the number of the dendritic cells.
\end{abstract}

Key Words: chronic gingivitis, chronic periodontitis, immunological response, immunohistochemical.

\section{INTRODUCTION}

Periodontal disease is a chronic inflammatory infectious condition that affects the surrounding and/or supporting tissues of the teeth and, in which, like in other infections, bacteria-host interactions determine the nature of the resulting disease.

The immune response of the host organism to dental biofilm microorganisms can be either protective, destructive or both, contributing to the wide variety of tissue alterations observed in periodontal disease $(1,2)$.

Numerous studies have demonstrated variations in the number and/or density of lymphocyte subpopulations as well as in the number of plasma cells during different stages of periodontal disease. While T lymphocytes represent the predominant inflammatory cell type in early and stable periodontal lesions, B lymphocytes and plasma cells predominate in advanced and progressive lesions, such as chronic periodontitis $(3,4)$. In addition to lymphocytes, macrophages represent another important cell type involved in host defense against bacterial aggression, accounting for about $5-30 \%$ of the inflammatory infiltrate found in periodontal lesions (4).

The purpose of this study was to determine the

Correspondence: Profa. Dra. Roseana de Almeida Freitas, Programa de Pós-Graduação em Patologia Oral, Departamento de Odontologia, Universidade Federal do Rio Grande do Norte, Avenida Senador Salgado Filho, 1787, 59056-000 Lagoa Nova, Natal, RN, Brasil. Tel/Fax: +55-84-3215-4138. e-mail: roseana@dod.ufrn.br 
immunohistochemical phenotype of cells that participate in the immune response in chronic gingivitis (CG) and chronic periodontitis (CP) and the profile of the cell population involved in this response in order to obtain data that might contribute to the assessment and understanding of the multiple and complex biological steps of the etiopathogenis of periodontal disease.

\section{MATERIAL AND METHODS}

This descriptive study was based on the observation, analysis and recording of the density of inflammatory cells in chronic gingivitis and periodontitis. In addition, dependent variables were compared between the two groups studied. Sample comprised 42 paraffinembedded tissue specimens clinically diagnosed as chronic gingivitis ( 17 cases) and periodontitis (25 cases), from the files of the Pathological Anatomy Service, Discipline of Oral Pathology, Department of Dentistry, Federal University of Rio Grande do Norte, Brazil.

\section{Morphological Analysis}

Initially, 5- $\mu \mathrm{m}$ thick, hematoxylin/eosin-stained histological sections, corresponding to the selected gingival specimens, were analyzed morphologically. Each case was examined by light microscopy for determination of the quality (lymphocytic, plasmacytic or lymphoplasmacytic) and intensity (discrete, moderate or intense) of the inflammatory infiltrate.

\section{Immunohistochemical Study}

All paraffin-embedded gingival specimens corresponding to the cases selected for this study were cut into $3-\mu \mathrm{m}$ thick histological sections, which were mounted on glass slides prepared with 3-aminopropyltriethoxy-silane adhesive (Sigma Chemical Co., St Louis, MO, USA). The sections were then submitted to immunohistochemistry by the streptavidin-biotin method (SABC) using the following primary antibodies: anti-CD4, anti-CD20, anti-CD25, antiCD68, and anti-S-100. The characteristics of the antibodies in terms of specificity, antigen recovery treatment, dilution and time of incubation are shown in Table 1.

\section{Analysis of Immunostained Cells}

Light microscopy was used to determine the mean number per field of anti-S-100 protein-positive cells and the density of cells labeled for anti-CD4, antiCD20, anti-CD25 and anti-CD68 antibodies in all chronic gingivitis and periodontitis specimens of the sample. The anti-S-100 antibody was determined in both gingival epithelium and lamina propria, while antiCD4, anti-CD20, anti-CD25 and anti-CD68 antibodies were analyzed in the lamina propria only.

In order to determine the intensity of cell immunostaining, scores from 0 to 3 were attributed: $0=$ absence of positive cells; $1=$ small number of positive cells or isolated cells; $2=$ moderate number of positive cells; and $3=$ large number of positive cells. The labeling intensity was evaluated by two previously trained examiners in a double-blind fashion.

For quantitative analysis of S-100+ cells, 10 sequential histological fields in the epithelium and 10 in the lamina propria were examined per slide. The total number of immunostained cells in these fields was recorded and the arithmetic means corresponding to each case were calculated. The mean number of S$100+$ cells per field was calculated for both the epithelial compartment (including the basal and suprabasal layers) and the lamina propria. Images of the fields were captured with an Olympus CH30 light microscope (Olympus Optical, Tokyo, Japan) at $\times 400$ magnification under a fixed focus.

\section{Statistical Analysis}

Dependent variables of the ordinal qualitative type (density of CD4+, CD20+, CD25+ and CD68+

Table 1. Monoclonal antibodies used.

\begin{tabular}{|c|c|c|c|c|}
\hline Antibody & Clone & Specificity & Dilution & $\begin{array}{l}\text { Incubation } \\
\text { time (min) }\end{array}$ \\
\hline CD4* & 1F6 & $\begin{array}{c}\text { T-help } \\
\text { lymphocytes }\end{array}$ & $1: 10$ & 120 \\
\hline CD20* & L26 & B lymphocytes & $1: 100$ & 120 \\
\hline $\mathrm{CD} 25 * *$ & $\begin{array}{c}\mathrm{Ab}-1 \\
\text { (IL2R.1) }\end{array}$ & IL-2R $\alpha$ & $1: 40$ & 60 \\
\hline CD68*** & KP1 & Macrophages & 1: 50 & Overnight \\
\hline S-100*** & $\begin{array}{l}\text { Cow } \\
\text { S-100 }\end{array}$ & $\begin{array}{c}\text { Dendritic } \\
\text { cells }\end{array}$ & $1: 400$ & 120 \\
\hline
\end{tabular}

*Novocastra Laboratories, Newcastle, UK; **NeoMarkers, Fremont, CA, USA; ***Dako Corporation, Carpinteria, CA, USA. 
cells) were submitted to nonparametric analysis (MannWhitney test) because of the absence of normality as determined by the Kolmogorov-Smirnov test and due to the characteristic of the variable itself. However, dependent variables of the discrete quantitative type (quantity of S-100+ cells), which showed a normal distribution, were analyzed by a parametric test (Student t-test). Significance level was set at $\alpha=0.05$ in both cases.

\section{RESULTS}

\section{Morphological Results}

All CG specimens (100\%) showed an intense inflammatory infiltrate, with the infiltrate being predominantly lymphocytic in 8 cases (47\%), lymphoplasmacytic in $3(17.7 \%)$ and predominantly plasmacytic in $6(35.3 \%)$.

Twenty-two (88\%) of the CP specimens examined showed an intense inflammatory infiltrate, while a moderate infiltrate was observed in only 3 cases $(12 \%)$. Lymphocytes were the predominant type of inflammatory cells in 8 cases $(32 \%)$, while 17 specimens $(68 \%)$ exhibited an inflammatory infiltrate ranging from lymphoplasmacytic ( 9 cases, 36\%) to predominantly plasmacytic (8 cases, 32\%).

\section{Immunohistochemical Results}

Qualitative Analysis of the Expression Pattern of CD4+ Cells in the Lamina Propria. All cases of CG

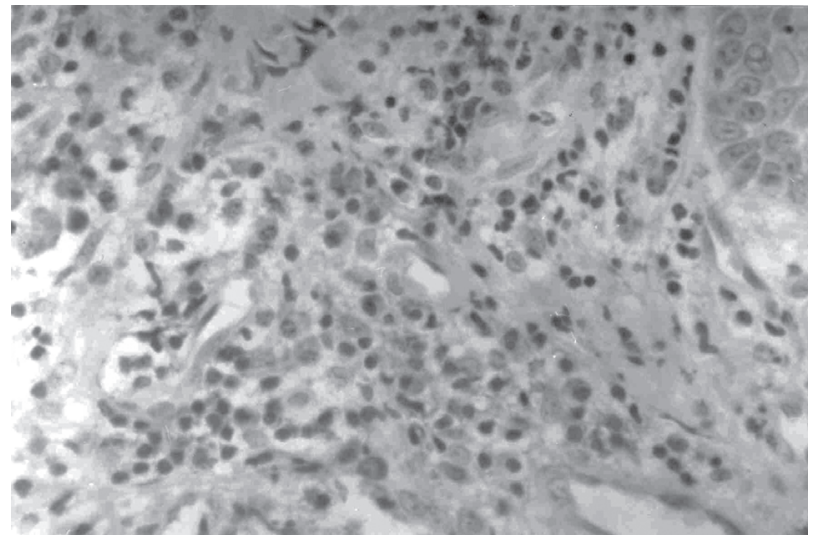

Figure 1. Foci of CD20+ cells/score 2 in chronic gingivitis $(\mathrm{SABC} ; \times 400)$. analyzed were immunoreactive to the anti-CD4 antibody, with positive cells being diffusely distributed in the form of isolated cells or in small foci consisting of scarce cells (score 1). Twenty-two (88\%) of the CP cases were positive for the CD4 marker. However, a reduced number of CD4+ cells (score 1) distributed in an isolated manner were observed in these specimens. Qualitative Analysis of the Expression Pattern of CD20+ Cells in the Lamina Propria. Sixteen (94.1\%) of the 17 cases of CG were positive for the anti-CD20 antibody, with the immunostained cells showing a predominantly focal distribution pattern. This pattern of cell distribution was characterized by the presence of foci showing variable labeling intensity consisting of a small (score 1), moderate (score 2) or large (score 3) number of positive cells. Score 2 predominated in 11 specimens (Fig. 1) and score 1 in only 5. Positive immunostaining for the anti-CD20 antibody was observed in $22(88 \%)$ of the $25 \mathrm{CP}$ specimens. Regarding the density of immunopositive cells, considering all cell distribution patterns analyzed, scores 2 and 1 predominated in 13 and 9 cases, respectively.

Qualitative Analysis of the Expression Pattern of CD25+Cells in the Lamina Propria. Sixteen $(94.1 \%)$ of the 17 cases of CG were positive for the CD25 marker. Score 2 predominated in 7 specimens, score 1 in 5 specimens, and score 3 in 4 cases, with scores 2 and 1 thus predominating in the CG sample. The total CP sample demonstrated immunoreactivity to the anti-CD25 antibody. With respect to the density of immunopositive cells, 16

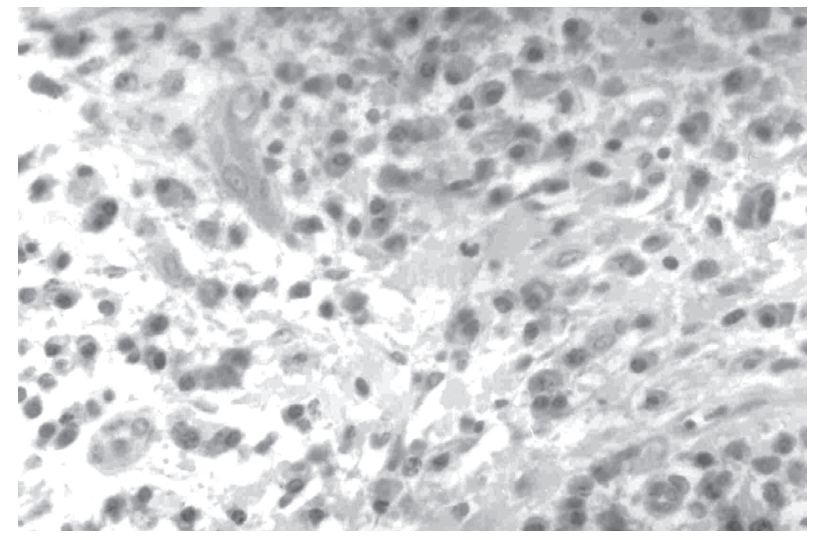

Figure 2. Chronic periodontitis. Diffuse distribution of CD25+ cells in the lamina propria/score $3(\mathrm{SABC} ; \times 400)$. 
specimens presented score 3 (Fig. 2), 7 showed score 2 , and only 2 presented score 1 , with scores 3 and 2 thus predominating in the total sample.

Qualitative Analysis of the Expression Pattern of CD68+Cells in the Lamina Propria. All cases of CG were immunoreactive to the anti-CD68 antibody, with score 2 predominating in more than half the sample (10 cases), followed by score 1 in 5 , and score 3 in only 2 cases. The total sample of CP was positive for the anti-CD68 antibody. Most specimens (18 cases) presented score 1 , while score 2 was observed in 7 cases.

Quantitative Analysis of the Expression Pattern of S-100+ Cells in Epithelium and Lamina Propria. Immunoreactivity to the anti-S-100 protein antibody was determined in only of CG, with the remaining specimens being discarded because of an insufficient number of histological fields ( 2 cases) or because of the lack of epithelial lining (1 case). Only one of the 14 gingival specimens was negative for the S-100 protein. Immunostaining for the S100 marker was observed in the whole sample of CP (Fig. 3). However, 2 specimens were discarded because of the lack of sufficient tissue fragments for cell counting.

\section{Statistical Analysis}

Density of $C D 4+, C D 20+, C D 25+$ and $C D 68+$ Cells in the Lamina Propria. Mann-Whitney nonparametric test was used to determine differences in the density of CD20+, CD25+ and CD68+ cells between the two groups studied (CG and $\mathrm{CP}$ ). The CD4 immunohis-

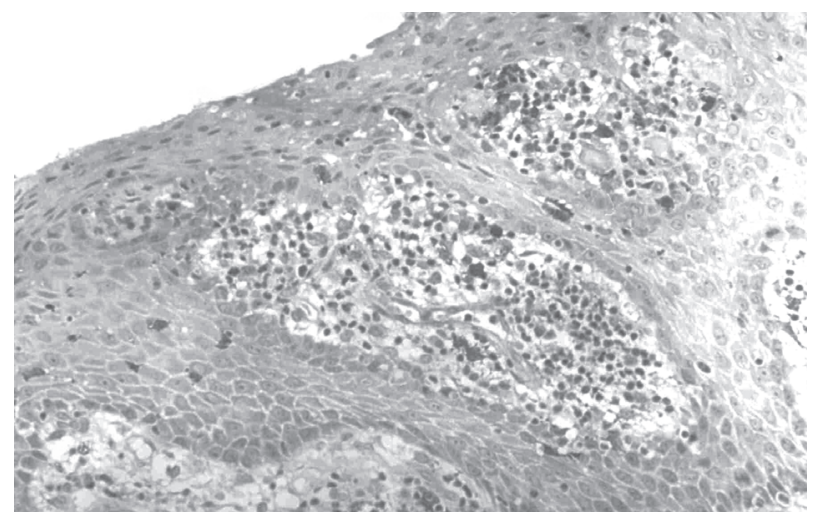

Figure 3. S-100+ cells in the epithelium and lamina propria chronic periodontitis specimen $(\mathrm{SABC} ; \times 200)$. tochemical marker was not analyzed because all values were the same, thus presenting a zero standard deviation. Only the anti-CD20 showed no significant difference between CG and CP $(\mathrm{p}=0.4414)$. Significant differences $(p<0.05)$ between groups were observed for the other antibodies (anti-CD25 and anti-CD68), with the density of CD25+ and CD68+ cells being significantly higher in chronic periodontitis and gingivitis, respectively.

Number of S-100+ Cells in Epithelium and Lamina Propria. Regarding the quantitative variables submitted to parametric analysis, no significant differences $(p>0.05)$ in the number of $S-100+$ cells were observed between the groups, irrespective of the site of analysis.

\section{DISCUSSION}

As established in the literature, the immune response to bacterial aggression plays a key role in periodontal disease $(1,3)$. This fact was demonstrated in the present study in which inflammation was intense in $94.1 \%$ of CG cases and in $88 \%$ of CP cases. Additionally, an inflammatory infiltrate was observed, ranging from lymphoplasmacytic to predominantly lymphocytic in $67.7 \%$ of the chronic gingivitis samples, and from lymphoplasmacytic to predominantly plasmacytic in $68 \%$ of chronic periodontitis specimens. These findings are consistent with those of other investigations that showed the presence of lymphocytes during all phases of periodontitis and a larger number of plasma cells in more advanced stages of the disease (4-7).

The density of CD68+ cells was higher in CG than in $\mathrm{CP}$, in agreement with the findings of previous studies (4-6). These investigators stated that a reduction in macrophage density in chronic periodontitis can also be attributed to the migration of these cells to regional lymph nodes for antigen presentation.

With respect to $\mathrm{T}$ lymphocyte density in chronic gingivitis, the present results do not agree with the literature, as most studies implicate T lymphocyte as the main cell type found in the inflammatory infiltrate during the initial stages of gingivitis $(8,9)$. A labeling intensity score of 1 for CD4+ cells was exclusively observed in CP specimens, corroborating the studies of Kleinfelder et al. (10). The fact that this experiment was restricted to the investigation of $\mathrm{CD} 4+\mathrm{T}$ lymphocytes also seems to explain the reduced density of positive $\mathrm{T}$ cells 
observed in this sample because, even in small numbers, CD8+ T lymphocytes are also present in $\mathrm{CP}$, as reported by Séguier et al. (11).

The expression of CD20+ cells, indicative of B lymphocytes, was observed in $94.1 \%$ of CG cases and in $88 \%$ of CP cases, with a predominantly focal distribution. This organization of CD20+ cells can be attributed to an attempt of these cells to mimic the formation of germinative centers. These findings disagree with those obtained by other authors $(5,6)$, who reported the existence of a larger number of $\mathrm{B}$ lymphocytes in $\mathrm{CP}$ compared to CG. According to the same authors $(5,6)$, $\mathrm{CG}$ is characterized by numerical variations in $\mathrm{T}$ and $\mathrm{B}$ lymphocytes, depending on their stage of development, with $\mathrm{T}$ lymphocytes predominating in incipient gingivitis and B lymphocytes in already established lesions. Therefore, the similarity in CD20+ cell density observed in the present for both groups might be explained by the fact that most CG cases were in fact established and not incipient gingivitis.

The marked presence of plasma cells in $\mathrm{CG}$ specimens and their quantitative increase in cases of $\mathrm{CP}$ observed in the present study support previous suggestions regarding the duration of these lesions which, on the basis of these histological criteria, can be classified as established CG and advanced $\mathrm{CP}$, respectively, as proposed by Wikström et al. (12).

The monoclonal anti-CD25 antibody recognizes the a subunit of the IL- 2 receptor (IL-2R $\alpha$ ) expressed on the surface of active B lymphocytes as well as on natural killer cells and $\mathrm{T}$ lymphocytes in process of activation (13), this antibody representing an excellent marker of cell activation (2).

The lymphocyte infiltrate (CD25+) was more intense in $\mathrm{CP}$ (score 3) than in $\mathrm{CG}$ (score 2), in agreement with the study of Yamazaki et al. (14). This finding explains the greater tissue destruction observed in advanced periodontal disease in view of the elevated secretion of catabolic and bone resorptive cytokines by activated $\mathrm{T}$ helper lymphocytes (Th1 and Th2) and the abundant production of antibodies by plasma cells. These results suggest that acute outbreaks of periodontal disease activity are associated with a quantitative increase in CD25+ cells.

Regarding the identification of dendritic cells, we chose to use the anti-S-100 protein immunohistochemical marker because it is effective in the labeling of these cells, although it also identifies cells of neural origin.
Langerhans cells were present in the oral gingival epithelium, equally occupying the basal and suprabasal layers, and, eventually, in the sulcular epithelium. These findings agree with those reported elsewhere $(15,16)$, who found these cells distributed within basal and suprabasal keratinocytes of the mucosal squamous epithelium, irrespective of a status of health or disease.

The activation of Langerhans cells by antigen captured in epithelial tissue accompanied by the release of inflammatory mediators decreases the levels of Ecadherin (a cellular adhesion molecule), which, in turn, reduces the interaction of these cells with keratinocytes, permitting their migration to regional lymph nodes (17). This fact might explain the presence of dendritic cells in the lamina propria of these specimens. With respect to the present study, it may be suggested that the S-100+ cells found in gingival connective tissue are, in fact, dendritic cells migrating to the regional lymph nodes for antigen presentation.

In contrast, according to Dereka et al. (18), the presence of dendritic cells in gingival connective tissue, especially in papillary and perivascular regions, suggests that the numerical increase of Langerhans cells in gingival epithelium probably results from the migration of these cells from the blood vessels of the lamina propria to the epithelial tissue in response to greater bacterial aggression. Comparing the number of Langerhans cells (S-100+) present in epithelial tissue with the degree of gingival inflammation. The lack of significant numerical differences in Langerhans cells between CG and $\mathrm{CP}$ specimens can be explained by the fact that the inflammatory infiltrate was found to be intense in all cases immunoreactive to the $\mathrm{S}-100$ protein and, therefore, no variation in the level of gingival inflammation was observed between the studied groups, in contrast to the findings of previous investigations $(16,19)$.

This strong correlation between the expression of Langerhans cells and gingival inflammatory infiltrate might represent a reflex of the immunomodulatory activity of these cells on the magnitude of the inflammatory response, since this cell population is the main antigen-presenting cell in gingival tissue (20).

In conclusion, the immune response in periodontal disease (chronic gingivitis and periodontitis) involves the effective participation of different types of cells such as macrophages, $\mathrm{T}$ and $\mathrm{B}$ lymphocytes, and dendritic cells. The higher density of macrophages suggests the participation of these cells in the pathogen- 
esis of gingivitis, while the higher concentration of B lymphocytes compared to $\mathrm{T}$ lymphocytes both in gingivitis and periodontitis suggests a greater role of the humoral immune response in the different stages of periodontal disease. In contrast, the higher density of CD25+ cells in periodontitis indicates a greater cell activation of the lymphocytic infiltrate, whereas Langerhans cells seem to play a similar role in the two conditions studied since no difference was observed between groups.

\section{RESUMO}

Com o objetivo de contribuir para um melhor entendimento na etiopatogenia da doença periodontal, um análise imunohistoquímica da densidade das células inflamatórias mononucleares e da quantidade das células dendríticas foi realizada utilizando os anticorpos anti-CD4, anti-CD20, anti-CD25, anti-CD68 and anti-proteína S-100 em 17 casos de gengivite crônica (GC) e 25 casos de periodontite crônica (PC). As células CD4+ e CD68+ exibiram distribuição difusa no tecido conjuntivo, enquanto que a distribuição das células CD20+ foi predominantemente em grupos, e as CD25+ exibiram distribuição ora difusa ora focal. As células S-100+ foram identificadas no epitélio e na lamina própria, exibindo morfologia e números distintos. A análise estatística não demonstrou diferenças estatisticamente significativas em relação a densidade das células CD4+e CD20+e no número de células S$100+$ entre os casos de CG e PC. Entretanto, houve diferenças em relação a densidade das células CD25+e CD68+entre os grupos $(\mathrm{p}<0,05)$. A densidade dos macrófagos foi maior em GC e o nível de ativação celular do infiltrado linfocítico foi maior em PC, não havendo diferenças em relação a densidade de linfócitos $\mathrm{T}$ e B, bem como no número de células dendríticas entre as condições anteriormente mencionadas.

\section{REFERENCES}

1. Van Dike TE, Serhan CN. Resolution of inflammation: a new paradigm for the pathogenesis of periodontal diseases. J Dent Res 2003;82:82-90.

2. Karimzadeh K, Morrison J, Zadeh HH. Comparison of gingival and peripheral blood $\mathrm{T}$ cells among patients with periodontitis suggests skewing of the gingival $\mathrm{T}$ cell antigen receptor V beta repertoire. J Periodont Res 1999;34:445456.

3. Offenbacher S. Periodontal diseases: pathogenesis. Ann Periodontol 1996;1:821-878.

4. Mikhaleva LM, Barkhina TG, Shapovalov VD, Luss LV, Il'ina NI. Ultrastructure of cell populations of gingival soft tissue in chronic inflammatory processes. Arkhiv Patol 2001;63:15-21.

5. Katz J, Michalek, SM. Effect of immune T cells derived from mucosal or systemic tissue on host responses to Porphyromonas gingivalis. Oral Microbiol Immunol 1998; 13:73-80
6. Gamonal J, Acevedo A, Bascones A, Jorge O, Silva A. Characterization of cellular infiltrate, detection of chemokine receptor CCR5 and interleukin-8 and RANTES chemokines in adult periodontitis. J Periodont Res 2001;36:194-203.

7. Apsey DJ, Kaciroti N, Loesche WJ. The diagnosis of periodontal disease in private practice. $\mathrm{J}$ Periodontol 2006;77:1572-1581.

8. Gemmell E, Seymour GJ. Cytokine profiles of cells extracted from humans with periodontal diseases. J Dent Res 1998;77:16-26.

9. Séguier S, Godeau G, Leborgne M, Pivert G, Brousse N. Immunohistologic and morphometric analysis of cytotoxic $\mathrm{T}$ lymphocytes in gingivitis. J Periodontol 1999;70:1383-1391.

10. Kleinfelder JW, Lange DE, Bocker W. Some effects of nonsurgical therapy gingival inflammatory cell subsets in patients with adult and early-onset periodontitis. J Periodontol 2000;71:1561-1566.

11. Séguier S, Godeau G, Brousse N. Collagen fibers and inflammatory cells in healthy and diseased human gingival tissues: a comparative and quantitative study by immunohistochemistry and automated image analysis. J Periodontol 2000;71:1079-1085.

12. Wikstrom M, Wennstrom JL, Renvert S, Jonsson R. Immunohistological characteristics of periodontal lesions associated with Porphyromonas gingivalis and Actinobacillus actinomycetemcomitans infections. Oral Microbiol Immunol 1996;11:1-7.

13. Tkaczuk J, Yu CL, Baksh S, Milford EL, Carpenter CB, Burakoff SJ, McKay DB. Effect of anti-IL-2Ralpha antibody on IL-2-induced Jak/STAT signaling. Am J Transplant 2002;2:31-40.

14. Yamazaki K, Nakajima T, Aoyagi T, Hara K. Immunohistological analysis of memory $\mathrm{T}$ lymphocytes and activated $\mathrm{B}$ lymphocytes in tissues with periodontal disease. J Periodont Res 1993;28:324-334.

15. Misery L, Dezutter-Dambuyant C. Precursors of Langerhans cells. J Europ Acad Dermatol Venereol 1995;5:124-131.

16. Seguier S, Godeau G, Leborgne M, Pivert G, Brousse N. Quantitative morphological analysis of Langerhans cells in healthy and disease human gingiva. Arch Oral Biol 2000;45:10731081 .

17. Keller R. Dendritic cells: their significance in health and disease. Immunol Let 2001;78:113-122.

18. Dereka XE, Tosios KI, Chrysomali E, Angelopoulou E. Factor XIIIa+ dendritic cells and S-100 protein+ Langerhans' cells in adult periodontitis. J Periodontal Res 2004;39:447452.

19. Bodineau A, Godeau G, Brousse N, Pellat B, Folliguet M, Seguier S. Langerhans cells express matrix metalloproteinases 9 and 2 and tissue inhibitors of metalloproteinases 1 and 2 in healthy human gingival tissue and in periodontitis. Oral Microbiol Immunol 2006;21:197-200.

20. Séguier S, Godeau G, Brousse N. Immunohistological and morphometric analysis of intra-epithelial lymphocytes and Langerhans cells in healthy and disease human gingival tissues. Arch Oral Biol 2000;45:441-452.

Accepted June 5, 2007 